\title{
Contact hypersensitivity to nickel in patients with atopic dermatitis
}

\section{Nadwrażliwość kontaktowa na nikiel u pacjentów chorych na atopowe zapalenie skóry}

Michał Rożalski, Leszek Blicharz, Zbigniew Samochocki

Department of Dermatology, Warsaw Medical University, Warsaw, Poland

Katedra i Klinika Dermatologiczna Warszawskiego Uniwersytetu Medycznego, Polska

Dermatol Rev/Przegl Dermatol 2017, 104, |33-141 DOI: https://doi.org/l0.5। |4/dr.2017.67388

\author{
CORRESPONDING AUTHOR/ \\ ADRES DO KORESPONDENCJI: \\ Michał Rożalski \\ Klinika Dermatologiczna \\ Warszawski Uniwersytet \\ Medyczny \\ ul. Koszykowa 82 A \\ 02-008 Polska \\ tel.: +48791427865 \\ e-mail: michal_rozalski@vp.pl
}

\begin{abstract}
Atopic dermatitis is a chronic, recurrent inflammatory dermatosis with a complex and not fully explained pathogenesis. Recent years' research points to a significant percentage of patients with atopic eczema in whom hapten patch test results are positive, especially with respect to nickel. These observations undermine suggestions that contact allergy (type IV hypersensitivity) is rare in this group due to the dominance of the Th2-type cellular response characteristic for type I allergic reactions. In this review we aimed to systematize current knowledge regarding the pathomechanisms of contact hypersensitivity to nickel in patients with atopic dermatitis and the potential influence of this hapten on the clinical course of the disease.
\end{abstract}

\section{STRESZCZENIE}

Atopowe zapalenie skóry jest przewlekłą, nawrotową dermatozą zapalną o złożonej, nie w pełni wyjaśnionej etiopatogenezie. Badania $\mathrm{z}$ ostatnich lat wskazują na istotny odsetek chorych na wyprysk atopowy, u których stwierdza się dodatnie wyniki płatkowych testów kontaktowych z haptenami, głównie z niklem. Obserwacje te przeczą sugestii, że w tej grupie pacjentów alergia kontaktowa (IV mechanizm nadwrażliwości) jest rzadkim zjawiskiem ze względu na przewagę odpowiedzi komórkowej typu Th2, typowej dla I mechanizmu nadwrażliwości. W poniższej pracy autorzy podjęli próbę usystematyzowania dotychczasowej wiedzy o patomechanizmie rozwoju nadwrażliwości kontaktowej na nikiel u chorych na atopowe zapalenie skóry i ewentualnym wpływie tego haptenu na kliniczny przebieg schorzenia.

Key words: atopic dermatitis, allergic contact dermatitis, nickel. Słowa kluczowe: atopowe zapalenie skóry, alergiczne kontaktowe zapalenie skóry, nikiel. 


\section{INTRODUCTION}

Atopic dermatitis (AD) is a chronic, recurrent inflammatory dermatosis with a characteristic morphology and location of skin lesions, accompanied by pruritus of variable severity. The onset of this disease is usually associated with early childhood. Over the last decades AD prevalence has reached $15-30 \%$ in children and $2-10 \%$ in adults [1].

The pathogenesis of AD is complex and not fully understood. It is believed that atopic eczema is associated with epithelial barrier dysfunction and quantitative/qualitative disorders of the innate and acquired immunological system. It develops in genetically predisposed individuals under the influence of numerous environmental factors. Various chromosomes show dysfunctions of genes for cytokines involved in the production of IgE, chemokines, protease/protease inhibitors and the "epidermal differentiation complex" in this group of patients [2].

In 2004 the European Academy of Allergy and Clinical Immunology (EAACI) distinguished two forms of AD: atopic and non-atopic eczema [3]. Nevertheless, they are both universally referred to as "atopic dermatitis" in the medical literature. Two types of $\mathrm{AD}$ can be distinguished: extrinsic AD (eAD) $(80 \%$ of AD cases), associated with increased total IgE levels, presence of specific IgE directed against food and/or aero-allergens, and concomitant atopic diseases affecting the airways; and intrinsic AD (iAD) ( $20 \%$ of AD cases), in which these characteristics are not present $[4,5]$.

Development of skin lesions in AD is associated with T lymphocyte imbalances (mainly of the 4 populations - Th1, Th2, Th17, Treg) which results in the disproportion of secreted cytokines [6]. The Th2 cytokine profile (IL-4, IL-5, IL-13; I hypersensitivity mechanism) is observed in acute inflammatory lesions, while chronic changes are characterized by the Th1 cytokine profile characteristic for type IV hypersensitivity (IL-5, GM-CSF, IL-12, IFN- $\gamma$ ). Mainly due to IL-4 secretion, Th2 lymphocytes cause class E immunoglobulin production through stimulation of $B$ cells and increase the expression of Fc receptors for IgE. Simultaneously, Th1-dependent production of IFN- $\gamma$, IL-1, IL-2 and TNF- $\alpha$ is reduced [6]. It has been postulated that the dominance of Th1 lymphocytes in chronic skin lesions may be secondary to effects mediated by IL-12. IL-12 is released by eosinophils, whose influx is stimulated by Th2 lymphocytes [7] as well as by the inflammatory dendritic epidermal cells (IDECs) [8]. Peripheral blood samples of AD patients have shown an increased Th17 concentration, while skin samples reveal presence of these cells only during acute inflammation [9]. IL-17 and IL-22 syn-

\section{WPROWADZENIE}

Atopowe zapalenie skóry (AD) jest przewlekłą, nawrotową dermatozą zapalną o charakterystycznej morfologii oraz lokalizacji zmian wypryskowych, którym towarzyszy różnie nasilony świąd. Choroba rozpoczyna się zwykle w okresie wczesnego dzieciństwa. W ostatnich dekadach częstość występowania AD wzrosła do 15-30\% u dzieci i 2-10\% u dorosłych [1].

Etiopatogeneza AD jest złożona i nie w pełni poznana. Przyjmuje się, że choroba wiąże się z dysfunkcją bariery naskórkowej oraz zaburzeniami ilościowymi lub czynnościowymi wrodzonego i nabytego systemu immunologicznego. Występuje u osób predysponowanych genetycznie pod wpływem różnych czynników środowiskowych. U chorych na wyprysk atopowy stwierdzono na różnych chromosomach dysfunkcje genów cytokin zaangażowanych w regulację syntezy IgE, chemokin, proteaz i ich inhibitorów oraz tzw. kompleksu różnicowania komórek nabłonka [2].

W 2004 r. European Academy of Allergy and Clinical Immunology (EAACI) rozróżniła AD jako wyprysk o podłożu atopowym lub nieatopowym [3]. Powszechnie jednak w piśmiennictwie medycznym stosuje się określenie atopic dermatitis. Dzieli się go na 2 podtypy: extrinsic (eAD) (80\% przypadków), związany z podwyższonym stężeniem całkowitego IgE, obecnością swoistych przeciwciał IgE skierowanych przeciwko alergenom pokarmowym i/lub powietrznopochodnym i towarzyszącymi chorobami atopowymi dróg oddechowych, oraz podtyp intrinsic (iAD) (20\% przypadków), w którym nie stwierdza się opisanych cech $[4,5]$.

Rozwój zmian zapalnych skóry w AD wiąże się z zaburzeniami równowagi pomiędzy limfocytami T (głównie 4 populacji - Th1, Th2, Th17 i Treg), co prowadzi do dysproporcji wydzielanych przez nie cytokin [6]. W obrębie zmian ostro zapalnych obserwuje się profil cytokin charakterystyczny dla Th2 (IL-4, IL-5 i IL-13; I mechanizm alergiczny), a w obrębie zmian przewlekłych - dla IV mechanizmu alergicznego związanego z Th1 (IL-5, GM-CSF, IL-12, INF- $\gamma$ ). Limfocyty Th2, głównie poprzez wydzielanie IL-4, pobudzają limfocyty B do produkcji przeciwciał klasy E oraz zwiększają ekspresję receptora Fc dla IgE. Jednocześnie synteza INF- $\gamma$, IL-1, IL-2, TNF- $\alpha$ przez limfocyty Th1 jest obniżona [6]. Przypuszcza się, że przewaga limfocytów Th1 w przewlekłych zmianach skórnych może być wynikiem działania IL-12. Jest ona uwalniana przez eozynofile, których napływ do ognisk zapalnych w skórze stymulują cytokiny uwalniane przez limfocyty Th2 [7], a także przez zapalne komórki dendrytyczne naskórka (IDECs) napływające do naskórka w trakcie zapalenia [8]. Wykazano także w krwi obwodowej chorych na AD podwyższone stężenie Th17, natomiast w wycinkach skór- 
thesized by these lymphocytes activate the expression of antimicrobial peptides (AMP), TNF- $\alpha$ and IL-8 in the epidermis, which escalates the inflammatory state [10]. The Th17 response is especially prominent in iAD [11].

Investigation of Treg lymphocytes in the context of AD pathogenesis has revealed an increased lifespan of these cells in peripheral blood samples of patients with atopic eczema, which correlated with SCORAD (SCORing Atopic Dermatitis) scale values. A correlation between clinical state and Treg cytokines (positive for IL-6 and negative for IL-10 and TNF- $\alpha$ ) has also been reported [12].

Langerhans cells are the main group of myeloid dendritic cells that are present in the non-lesional skin of AD patients. They are characterized by a significant concentration of high-affinity IgE receptors (FceRI) in eAD, which is not observed in iAD [13]. These receptors bind sIgE, thanks to which Langerhans cells can present food and airborne peptide antigens to immunocompetent cells. Once they have bound an allergen, Langerhans cells move to the lymph nodes, where they present it in a processed form to naïve $\mathrm{T}$ cells, which subsequently elicits a Th2 response. In patients who have already developed hypersensitivity to a given allergen, Langerhans cells can present it to the previously sensitized $\mathrm{T}$ cells and cause an inflammatory reaction. After they come into contact with an allergen and an inflammatory state develops, the number of Langerhans cells in the epithelium decreases, and a different population of FceRI-bearing myeloid DCs called inflammatory dendritic epidermal cells (IDECs) increases instead. These cells are found in large numbers within the epithelium of chronic inflammatory lesions. IDECs are found mainly in the inflamed regions of the skin, where they produce large amounts of cytokines after FceRI cross-linking, which aggravates the inflammatory state. Activation of IDECs' FceRI causes secretion of IL-12, whose presence increases the Th1 immune response in the skin [8]. The described mechanisms explain the development of eczematous lesions in the aftermath of exposure to protein allergens.

Allergic contact dermatitis (ACD) is an inflammatory dermatosis associated with type IV hypersensitivity mediated by Th1 lymphocytes (IFN- $\gamma$ ). The prevalence of ACD is estimated at approximately $20 \%$. Its development depends on the allergic properties of a hapten, severity of exposure, presence of previous skin irritation, damage of protective epithelial barrier, genetic predisposition, sex, age and race [14].

Contact allergens are non-protein molecules (haptens) under $500 \mathrm{Da}$ in size such as ions and salts of nickel, cobalt and chromium, flavoring substances, nych komórki te występują jedynie w okresie zmian ostro zapalnych [9]. Syntetyzowane przez te limfocyty IL-17 i IL-22 aktywują ekspresję białek przeciwbakteryjnych (AMP), TNF- $\alpha$ i IL-8 w naskórku, przez co nasila się stan zapalny [10]. Odpowiedź typu Th17 jest szczególnie wyraźna w iAD [11].

Obserwacje dotyczące roli Treg w patogenezie AD wykazały wydłużony czas przeżycia tych komórek i ich zwiększony odsetek w krwi obwodowej chorych, który korelował z wartościami SCORAD. Stwierdzono także zależność pomiędzy stanem klinicznym i stężeniem we krwi cytokin syntetyzowanych przez Treg (odpowiednio pozytywną dla IL-6 i negatywną dla IL-10 i TNF- $\alpha$ ) [12].

Komórki Langerhansa są głównymi komórkami dendrytycznymi pochodzenia szpikowego występującymi w skórze niezmienionej pacjentów z AD. U chorych z eAD charakteryzują się obecnością dużej liczby receptorów o wysokim powinowactwie do IgE (FceRI), czego nie obserwuje się u pacjentów z iAD [13]. Receptory te łączą się z sIgE, dzięki czemu komórki Langerhansa mogą prezentować białkowe antygeny pokarmowe i powietrznopochodne komórkom immunologicznie kompetentnym. Po połączeniu z alergenem komórki te przemieszczają się do węzłów chłonnych, gdzie prezentują przetworzone alergeny naiwnym komórkom $\mathrm{T}$, co powoduje odpowiedź typu Th2. U pacjentów, u których wystąpiła już alergia na dany alergen, komórki Langerhansa mogą go prezentować uwrażliwionym komórkom T w skórze, co powoduje odpowiedź zapalną. Kontakt z alergenem i powstanie stanu zapalnego powoduje zmniejszenie liczby komórek Langerhansa w naskórku, w zamian zwiększa się liczba zapalnych, naskórkowych komórek dendrytycznych pochodzenia szpikowego z receptorami FceR (IDECs). W przewlekłych zmianach zapalnych komórki te są wykrywane w dużych ilościach w naskórku. IDEC występują głównie w skórze zmienionej zapalnie, gdzie produkują liczne cytokiny prozapalne na skutek aktywacji receptorów FcદRI, co dodatkowo zaostrza stan zapalny. Aktywacja receptora FceRI na powierzchni IDEC powoduje wydzielanie IL-12, które wpływają na zwiększenie odpowiedzi typu Th1 w skórze [8]. Opisany mechanizm tłumaczy rozwój zmian wypryskowych pod wpływem alergenów białkowych.

Wyprysk kontaktowy alergiczny (ACD) jest dermatozą zapalną skóry związaną z nadwrażliwością typu IV - odpowiedź typu Th1 (INF- $\gamma$ ). Częstość występowania ACD szacuje się na ok. 20\%. Jej rozwój zależy od właściwości uczulającej haptenu, nasilenia ekspozycji na dany hapten, obecności podrażnienia skóry, uszkodzenia bariery ochronnej naskórka, predyspozycji genetycznej, wieku, płci i rasy [14].

Alergenami kontaktowymi są małe, niebiałkowe cząsteczki (hapteny) o masie poniżej 500 Da, takie jak: jony i sole metali niklu, kobaltu i chromu, substancje 
preservatives or pigments. In order for the allergy to develop, a hapten must penetrate through the superficial layers of the epithelium and connect with a protein. Epithelial penetration of haptens is facilitated by mechanical damage, maceration, dryness or epidermal inflammation. After allergens are bound by Langerhans cells or skin dendritic cells, they are presented in local lymph nodes via major histocompatibility complex class II (MHC II) to T-cell receptor (TCR) receptors of naïve T lymphocytes. This results in the appearance of T effector cells (CD8 Th1/Th17 and CD4 Th1/Th17) (sensitization phase). Dendritic cells present the antigens to NK cells as well, which stimulates the latter to IL-4 production. This cytokine prompts the development of B lymphocytes that produce hapten-specific class $\mathrm{M}$ immunoglobulins $[15,16]$. Another contact with the same allergen causes DCs (Langerhans cells and dendritic cells of the dermis) to bind it and present it via MHC II to Th1 lymphocytes that subsequently produce IFN- $\gamma$, TNF- $\alpha$ and IL-1. As a result, migration of T effector lymphocytes, neutrophils and monocytes to the skin occurs, which leads to the development of eczematous lesions (elicitation phase). IgM antibodies produced in the sensitization phase react with a specific hapten. Together they create immunological complexes that activate the complement via the classical pathway [16].

\section{CONTACT HYPERSENSITIVITY TO NICKEL}

Out of 3000 known contact allergens, nickel is one of the most widespread and best studied haptens causing contact hypersensitivity. It can be found in jewelry, metal buttons, zippers, glasses frames, coins, metal parts of watches, belt buckles and mobile phones [17]. In 1994 the European Union issued a decree specifying the limits of nickel excretion by items that have direct contact with human skin at $0.5 \mu \mathrm{g} / \mathrm{cm}^{2} /$ week. This number was restricted to $0.2 \mu \mathrm{g} / \mathrm{cm}^{2} /$ week for items introduced into pierced parts of the human body. After these regulations were accepted, a significant reduction of hypersensitivity to nickel was noted. In spite of these precautions, nickel remains the most common contact allergen in the European population. It is responsible for ACD in 65 million people $[17,18]-17 \%$ of women and $3 \%$ of men [19]. Risk of hypersensitivity development is increased when direct exposure to the hapten occurs within skin deprived of an epithelial barrier. Such a situation takes place e.g. as a result of body piercing (bypass theory), which would explain the higher prevalence of allergy to nickel in women [19].

It has been demonstrated that in patients with ACD caused by nickel, inflammatory cells obtained zapachowe, konserwanty oraz barwniki. Do rozwoju alergii potrzebne jest wniknięcie haptenu przez górne warstwy naskórka i połączenie się z białkiem. Zwiększona penetracja haptenów w głąb naskórka jest możliwa dzięki mechanicznemu uszkodzeniu naskórka, maceracji, suchości lub obecności stanu zapalnego. Następnie po wchłonięciu alergenu przez komórki Langerhansa czy skórne komórki dendrytyczne cząsteczki te prezentowane są przez cząsteczki MHC II w pobliskich węzłach chłonnych dziewiczym limfocytom $\mathrm{T}$ - receptorowi TCR limfocyta. Prowadzi to do powstania limfocytów T efektorowych (CD8 Tc1/Tc17 i CD4 Th1/Th17) (faza sensytyzacji). Komórki dendrytyczne prezentują antygeny komórkom NK, co stymuluje je do produkcji IL-4. Interleukina ta powoduje powstanie limfocytów B produkujących IgM swoistych dla danego haptenu $[15,16]$. Po kolejnej ekspozycji na dany alergen komórki dendrytyczne (Langerhansa i komórki dendrytyczne skóry właściwej) prezentują alergen limfocytom Th1 za pomocą MHC II i powodują wydzielenie IFN- $\gamma$, TNF- $\alpha$ i IL-1 przez te limfocyty. Dochodzi do przemieszczenia się do skóry efektorowych limfocytów T, neutrofilów i monocytów powodujących powstanie zmian wypryskowych (elicitation phase). Przeciwciała IgM powstałe $\mathrm{w}$ fazie sensytyzacji reagują ze swoistym haptenem i tworzą kompleksy immunologiczne aktywujące układ dopełniacza na drodze klasycznej [16].

\section{NADWRAŻLIWOŚĆ KONTAKTOWA NA NIKIEL}

Spośród 3000 znanych alergenów kontaktowych nikiel jest jednym z najczęstszych i najlepiej poznanych haptenów wywołujących alergię kontaktową. Występuje w biżuterii, metalowych guzikach, zamkach błyskawicznych, oprawkach okularów, monetach, metalowych częściach zegarków, sprzączkach od paska czy telefonach komórkowych [17]. W 1994 r. w Unii Europejskiej wydano zarządzenie określające limity wydzielania niklu przez produkty mające kontakt ze skórą do $0,5 \mu \mathrm{g} / \mathrm{cm}^{2} /$ tydzień. Dla kolczyków wkładanych do przekłutego ucha i innych części ciała ludzkiego ta wartość wynosi 0,2 $\mu \mathrm{g} / \mathrm{cm}^{2} /$ tydzień. Po tych regulacjach odnotowano znaczącą redukcję częstości występowania nadwrażliwości na ten metal. Pomimo to nikiel jest najczęstszym alergenem kontaktowym w populacji europejskiej. Odpowiada za wystąpienie ACD u ok. 65 milionów ludzi [17, 18] - 17\% kobiet i 3\% mężczyzn [19]. Bezpośrednia ekspozycja skóry na alergen z pominięciem naskórka powoduje wzrost ryzyka rozwoju tej nadwrażliwości. Taka sytuacja zachodzi w trakcie przekłuwania skóry kolczykami (bypass theory), czym tłumaczy się częstsze występowanie alergii na nikiel u kobiet [19]. 
from eczematous lesions and re-exposed to this element secrete large amounts of IL-5 and variable amounts of IFN- $\gamma$ and IL-4, which points to the presence of mixed Th1/Th2 rather than a pure Th1 response [20]. Another study revealed that peripheral blood mononuclear cells (PBMC) taken from patients with ACD (hypersensitivity to methylisothiazolinones) and submitted to the allergen respond with IL-2, IL-4, IL-5 and IL-13 production, which also suggests a mixed Th1/Th2 immune response [21].

Furthermore, nickel can activate the innate immune system, showing pro-inflammatory properties. Its contact with endothelial cells was shown to up-regulate ICAM-1, VCAM-1 and E-selectin, which facilitates leukocyte adhesion [22]. Additionally, endothelial expression of proinflammatory cytokines such as the monocyte-attracting chemokine CCL2/MCP1 has been reported. This phenomenon is observed 12-24 hours after exposure to nickel in patients allergic to this hapten and before reactive $\mathrm{T}$ cells can be revealed in the skin [23]. Furthermore, direct induction of the IKK2/NFK $\beta$ pathway has been observed in the endothelium. Its activation by nickel causes similar gene expression as exposure to TNF- $\alpha$ [24].

Immunological system activation can also be provoked by TLR4 activation. In this case nickel is bound directly to histidine (H456, H458), outside of the ligand-binding region of this receptor [25]. During the sensitization phase, TLR4 activation may cause stimulation and redistribution of antigen-presenting cells (APCs) to the lymph nodes with subsequent presentation of nickel bound by HLA to naïve T cells. The role of TLR4 in the elicitation phase has not been investigated yet $[22,23,25]$. Nickel can also directly react with TCR without the help of APCs [26].

When a patient sensitive to nickel becomes exposed to this hapten via the gastrointestinal tract [27], the appearance of new skin lesions or exacerbation of the previous ones may be reported. Dyshidrotic eczema, maculopapular rash and vasculitis have also been described in these patients. Additionally, pruritus aggravation and concomitant nausea, headache and malaise have been reported [27]. Some products containing large amounts of nickel are nuts, chocolate, cocoa, sunflower seeds, whole meal products, red beans, legumes, licorice and dried fruit [28, 29]. Excessive intake of the above results in increased hapten concentration in the serum $[28,29]$. The daily nickel dose in an average diet is 0.1-0.5 mg (maximally $0.9 \mathrm{mg}$ ). Research evaluating systemic nickel hypersensitivity revealed that oral intake of this element reached up to $5.6 \mathrm{mg} /$ day $[29,30]$. This raises a question whether this type of provocation is clinically significant in standard conditions.
Wykazano, że komórki zapalne pobrane ze zmian skórnych chorych na ACD sprowokowany niklem i poddane ponownej ekspozycji na nikiel wydzielają dużą ilości IL-5 i zmienne ilości IFN- $\gamma$ i IL-4, co wskazuje na mieszaną odpowiedź Th1/Th2, a nie czystą odpowiedź Th1 [20]. W kolejnym badaniu stwierdzono, że komórki jednojądrowe krwi obwodowej (PBMC) pobrane od pacjentów chorych na ACD wywołany metyloizotiazoliną i poddane działaniu tego alergenu u części z nich odpowiadają za produkcję IL-2, IL-4, IL-5 i IL-13, co także wskazuje na mieszaną odpowiedź Th1/Th2 [21].

Ponadto nikiel może aktywować wrodzony układ odpornościowy. Ma on działanie prozapalne po kontakcie z komórkami naskórka, gdzie dochodzi do pobudzania ICAM-1, VCAM-1 i E-selektyn, które mają wpływ na adhezję leukocytów [22]. Dodatkowo stwierdzono w naskórku wzrost ekspresji prozapalnych cytokin, takich jak chemokiny CCL2/MCP1 przyciągające monocyty. Zjawisko to obserwuje się po 12-24 godzinach od ekspozycji na nikiel u pacjentów uczulonych na ten hapten, zanim w skórze u pacjentów z ACD wykrywane są reaktywne limfocyty T [23]. Wykazano ponadto bezpośrednią indukcję szlaku IKK2/NFא $\beta$ w komórkach naskórka. Jego aktywacja przez nikiel powoduje podobną ekspresję genów jak działanie TNF- $\alpha$ [24].

Aktywacja systemu odpornościowego może być prowokowana także przez połączenie niklu z TLR4. Dochodzi do tego nie w miejscu wiązania dla ligandów, lecz bezpośrednio z histydyną (H456, H458) tego receptora [25]. Aktywacja receptora TLR4 przez nikiel w fazie sensytyzacji może powodować aktywację i przemieszczenie komórek prezentujących nikiel na cząsteczkach HLA i prezentację ich w węzłach chłonnych naiwnym limfocytom $\mathrm{T}$. Rola receptora TLR4 w fazie efektorowej nie jest obecnie poznana [22, 23, 25]. Nikiel może również powodować bezpośrednią reakcję z TCR limfocytów, bez udziału komórek prezentujących antygen (APC) [26].

Gdy pacjent zostanie poddany działaniu haptenu drogą pokarmową [27], można zaobserwować nasilenie istniejących zmian wypryskowych lub powstanie nowych ognisk zapalnych. Opisano także u tych chorych rozwój wyprysku dyshydrotycznego, osutki plamisto-grudkowej i zapalenia naczyń. Dodatkowo obserwowano nasilenie świądu z towarzyszącymi nudnościami, bólami głowy i osłabieniem [27]. Do pokarmów o dużej zawartości niklu zalicza się: orzechy, czekoladę, kakao, nasiona słonecznika, produkty pełnoziarniste, czerwoną fasolę, warzywa strączkowe, lukrecję i suszone owoce [28, 29]. Ich większe spożycie wpływa na wzrost stężenia haptenu w surowicy [28, 29]. W przeciętnej diecie dzienna dawka niklu wynosi 0,1-0,5 mg (maksymalnie $0,9 \mathrm{mg}$ ). W badaniach dotyczących układowej alergii na nikiel obciążenie doustne tym pierwiastkiem sięgało nawet 5,6 mg/dobę [29, 30]. 


\section{ATOPIC DERMATIS AND CONTACT NICKEL HYPERSENSITIVITY}

In the past an opinion prevailed that coexistence of $\mathrm{AD}$ and nickel-dependent $\mathrm{ACD}$ was not likely due to dominance of the Th2 response in AD [30]. Allergic contact dermatitis development was reported especially in patients in the chronic phase of AD when Th1 the cytokine profile dominates, which would seemingly confirm this theory.

Nevertheless, clinical experience showed that $\mathrm{AD}$ and ACD can develop in one patient. In the 1950s Calnan described eczematous lesions typical for AD in female patients with an allergy to nickel and wearing nickel garters [31]. In 1965 Shanon presented a group of patients with hypersensitivity to metals, whose skin lesions corresponded to AD; he called this phenomenon "pseudo-atopic dermatitis" [32]. Furthermore, a diet low in metals was demonstrated to alleviate skin lesions in some patients with AD [33].

The standard concept of atopic diseases as Th2-mediated and contact hypersensitivity as Th1-dependent is being undermined. Numerous reports point to a more complex immune response where both Th1 and Th2 lymphocytes play an important role [34, 35]. Additionally, the Th17 response [36] and Th2-mediated IL-31 expression in the skin of patients with $\mathrm{AD}$ and $\mathrm{ACD}$ [37] is what these two dermatoses may have in common.

The latest reports show that contact allergy to haptens in AD patients is similarly widespread as in the general population [38]. Allergic contact dermatitis prevalence in patients with atopic eczema was estimated at $13.6-27.4 \%$ and it was significantly higher in women [39]. Metals (especially nickel) and to a lesser extent flavorings [39] and bases of locally administered drugs were the most common allergens [40]. Allergic contact dermatitis provoked mainly by flavorings, chromium, nickel and lanolin was reported in $14.9-64.2 \%$ of the investigated pediatric population with AD [41-44]. This phenomenon was more widespread in children with hand and/ or feet eczema (43.8\%) than without this symptom $(16.0 \%)$ [43].

Research conducted in the Japanese population of AD patients demonstrated a higher percentage of nickel, cobalt and chromium hypersensitivity than in the general population $-25.5 \%, 20.9 \%$ and $16.3 \%$ respectively. This regularity was more prominent in patients with $\mathrm{AAD}(61.3 \%)$ than with eAD $(25.5 \%)$, and nickel, cobalt and chromium hypersensitivity was present in $41.9 \%, 38.7 \%, 22.6 \%$ and $16.4 \%, 10.9 \%, 12.7 \%$ respectively. This observation may be explained by the fact that iAD patients present a Th1-dependent cytokine profile charac-
Stąd rodzi się pytanie, czy w normalnych warunkach ta droga prowokacji ma istotne znaczenie kliniczne.

\section{ATOPOWE ZAPALENIE SKÓRY A NADWRAŻLIWOŚĆ KONTAKTOWA NA NIKIEL}

W przeszłości przeważał pogląd o ograniczonej możliwości wystąpienia nadwrażliwości kontaktowej u chorych na AD ze względu na przewagę odpowiedzi typu Th2 nad Th1 [30]. Miała to potwierdzać obserwacja, że ewentualny rozwój alergii kontaktowej w tej grupie pacjentów dotyczył głównie okresu przewlekłego choroby, gdy dominował profil cytokin Th1.

Doświadczenie kliniczne wskazywało jednak, że AD i ACD mogą się pojawiać u jednego pacjenta. W latach 50. XX wieku Calnan opisał zmiany wypryskowe typowe dla AD u pacjentek z alergią na nikiel noszących niklowane podwiązki [31]. W 1965 r. Shanon przedstawił pacjentów z alergią na metale, u których obraz kliniczny zmian skórnych odpowiadał AD, co zostało przez niego nazwane pseudo-atopic dermatitis [32]. Wykazano ponadto wpływ diety ubogiej w metale na zmniejszenie nasilenia zmian skórnych u części pacjentów z AD [33].

Standardowy pogląd, że choroby atopowe są związane z odpowiedzią zależną od limfocytów Th2, a wyprysk kontaktowy - od limfocytów Th1, jest podważany. Liczne badania wskazują na bardziej złożoną odpowiedź, gdzie te dwa typy reakcji zapalnej się mieszają [34, 35]. Dodatkowo AD i ACD łączy występowanie odpowiedzi typu Th17 [36], a także wysoka ekspresja w skórze IL-31 [37] syntetyzowanej przez limfocyty Th2.

W ostatnio publikowanych badaniach wykazano, że alergia kontaktowa na hapteny u chorych na AD jest podobnym zjawiskiem jak w populacji ogólnej [38]. Częstość występowania ACD u pacjentów z wypryskiem atopowym wynosi 13,6-27,4\% i jest istotnie większa u kobiet [39]. Najczęstszymi alergenami były metale, głównie nikiel, rzadziej substancje zapachowe [39] i podłoża leków stosowanych miejscowo [40]. Wyprysk kontaktowy alergiczny, prowokowany głównie przez substancje zapachowe, chrom, nikiel i lanolinę, obserwowano u 14,9-64,2\% dzieci chorych na AD [41-44]. Zjawisko to częściej stwierdzano u dzieci z wypryskiem rąk i/lub stóp (43,8\%) niż bez tego objawu $(16,0 \%)$ [43].

$\mathrm{W}$ badaniach przeprowadzonych $\mathrm{u}$ japońskich pacjentów z AD wykazano wyższy niż w populacji ogólnej odsetek nadwrażliwości na nikiel, kobalt i chrom - odpowiednio 25,5\%, 20,9\% i 16,3\%. Zjawisko to obserwowano częściej u chorych z iAD (61,3\%) niż z eAD $(25,5 \%)$, a częstość nadwrażliwości na nikiel, kobalt i chrom w tych podtypach AD wynosiła odpowiednio $41,9 \%, 38,7 \%, 22,6 \%$ oraz $16,4 \%, 10,9 \%$, $12,7 \%$. Obserwację tę można wytłumaczyć faktem, że 
teristic for ACD, and eAD patients Th2-dependent cytokine overproduction associated with atopic diseases. What is more, sweat of iAD patients revealed a higher nickel concentration than in the samples of eAD patients [45]. This may suggest that nickel excreted with the sweat may exacerbate skin lesions in iAD. Serum nickel levels were 7 times higher in iAD patients than in the eAD group and in the general population. Oral administration of nickel did not influence these values in patients with $\mathrm{AAD}$, which suggests considerable disorders of nickel metabolism in this group [44].

Filaggrin is a protein that ensures correct epithelial stratum corneum architecture and epidermal barrier function. In 2006 Palmer et al. [46] suggested that filaggrin (FLG) gene mutation was one of the pathogenetic factors in $\mathrm{AD}$, although this phenomenon is present in only $30-50 \%$ of patients [47]. It has also been demonstrated that patients with AD show decreased epithelial filaggrin expression even without the mutation of the FLG gene [48]. With respect to the fact that filaggrin contains histidine capable of nickel chelation, it has been proposed that FLG gene mutations may facilitate penetration of this metal through the epithelium. Histidine deficiency associated with impaired filaggrin synthesis would cause increased nickel penetration through the skin and subsequent immunization development. This hypothesis was confirmed by a study where 4 groups of patients were investigated: 1 . AD (-) and FLG mutation (-) 2. AD (-) and FLG mutation $(+), 3$. AD (+) and FLG mutation $(-)$ and 4 . AD $(+)$ and FLG mutation $(+)$. Patients with piercing were excluded from the trial in order to eliminate the possibility of direct contact between the epithelial barrier-deprived skin and nickel. Contact hypersensitivity to nickel was reported in $9.8 \%, 12.2 \%, 17.9 \%$ and $30 \%$ respectively. Furthermore, patients with filaggrin mutations showed a more pronounced skin reaction in patch tests [49]. It is generally accepted that FLG mutations are characteristic for eAD patients [50], which makes these reports discrepant with former research [51] and suggests other mechanisms of ACD development in patients with AD.

\section{CONCLUSIONS}

Allergic contact dermatitis provoked by haptens, especially by nickel, is not a rare comorbidity in AD patients. The clinical picture of these two dermatoses may be very similar. This points to the necessity of routine skin patch testing with the view of detecting additional factors potentially provoking the eczema in these patients. Local inflammation, administration of glucocorticoids and epithelial barrier disorders may affect the immunological state of the skin, which pacjenci z iAD charakteryzują się profilem cytokin zależnych od Th1 charakterystycznym dla wyprysku kontaktowego, a pacjenci z eAD - profilem zależnym od Th2, typowym dla atopii. Ponadto u pacjentów z iAD stwierdzono wyższe stężenie niklu w pocie $\mathrm{w}$ porównaniu $\mathrm{z}$ pacjentami z eAD [45]. Może to sugerować, że wydzielany z potem nikiel powoduje nasilenie zmian skórnych u chorych $\mathrm{z}$ iAD. U pacjentów z iAD obserwowano 7-krotnie wyższe stężenie niklu w surowicy w porównaniu z pacjentami z eAD i populacją ogólną. Nie stwierdzono zmiany tego stężenia u pacjentów $z$ iAD po doustnym obciążeniu niklem, co może sugerować istotne zaburzenia regulacji gospodarki niklem w tej grupie pacjentów [44].

Filagryna jest białkiem, które wpływa na prawidłową budowę warstwy rogowej naskórka i funkcję bariery naskórkowej. W 2006 r. Palmer i wsp. [46] wskazali mutację genu filagryny (FLG) jako jeden z czynników patogenetycznych $\mathrm{AD}$, chociaż zjawisko to obserwuje się u 30-50\% chorych [47]. Wykazano ponadto, że nawet przy braku mutacji genu FLG pacjenci z AD charakteryzują się obniżoną ekspresją filagryny w naskórku [48]. Zasugerowano, że mutacje filagryny u chorych na AD mogą zwiększać przenikanie niklu przez naskórek. Filagryna zawiera bowiem histydynę, która chelatuje nikiel. Niedobór histydyny związany z zaburzeniami syntezy filagryny może powodować, że niezwiązany w naskórku nikiel penetruje do skóry, co powoduje rozwój immunizacji. Hipotezę tę potwierdza badanie obejmujące 4 grupy chorych: 1) z AD (-) i mutacją flagryny (-), 2) z AD (-) i mutacją filagryny (+), 3) z AD (+) i mutacją filagyny (-) oraz 4) z AD (+) i mutacją filagryny (+). Z badań tych wyłączono osoby noszące kolczyki, aby wykluczyć możliwość bezpośredniego kontaktu niklu ze skórą z pominięciem bariery naskórkowej. Nadwrażliwość kontaktową na nikiel obserwowano odpowiednio u 9,8\%,12,2\%, 17,9\% i 30\% pacjentów. Ponadto pacjenci z mutacją filagryny mieli bardziej nasilone pozytywne wyniki testów skórnych [49]. Powszechnie uznaje się, że mutacje filagryny są cechą charakterystyczną dla pacjentów z eAD [50], co powoduje, że powyższe obserwacje są sprzeczne z doniesieniami [51] opisanymi wcześniej i sugerują jeszcze inne, nieznane czynniki predysponujące do rozwoju ACD u chorych na AD.

\section{PODSUMOWANIE}

Wyprysk kontaktowy alergiczny prowokowany przez hapteny, głównie nikiel, jest zjawiskiem nierzadkim u chorych na AD. Obraz kliniczny obu tych chorób bywa niekiedy bardzo zbliżony. Wskazuje to na potrzebę rutynowego wykonywania płatkowych testów kontaktowych u tych pacjentów w celu stwierdzenia kolejnych potencjalnych czynników prowokujących wyprysk. Należy pamiętać o wpływie na uzyskane wy- 
must be taken into consideration when interpreting the results. Because of these restrictions, patch tests should be performed when the lesions are mild or even in remission.

Due to the fact that the pathomechanism of ACD in $\mathrm{AD}$ remains unclear, additional multicenter studies of large, comparable groups of patients are needed in order to fully explain this phenomenon.

\section{CONFLICT OF INTEREST}

The authors declare no conflict of interest. niki statusu immunologicznego skóry związanego z nasileniem jej stanu zapalnego i miejscową aplikacją glikokortykosteroidów oraz zaburzeń barierowych. Dlatego też testy należy wykonywać w okresie niewielkiego nasilenia zmian skórnych bądź ich całkowitej remisji.

Patomechanizm rozwoju ACD w przebiegu AD jest nieznany, dlatego też konieczne są dalsze, wieloośrodkowe badania tego zjawiska w dużych, porównywalnych grupach pacjentów.

\section{KONFLIKT INTERESÓW}

Autorzy zgłaszają brak konfliktu interesów.

\section{References}

\section{Piśmiennictwo}

1. Bieber T.: Atopic dermatitis. Ann Dermatol 2010, 22, 125-137.

2. Werfel T., Allam J.P., Biedermann T., Eyerich K., Gilles S., Guttman-Yassky E., et al.: Cellular and molecular immunologic mechanisms in patients with atopic dermatitis. J Allergy Clin Immunol 2016, 138, 336-349.

3. Johansson S.G., Bieber T., Dahl R., Friedmann P.S., Lanier B.Q., Lockey R.F., et al.: Revised nomenclature for allergy for global use: Report of the Nomenclature Review Committee of the World Allergy Organization, October 2003. J Allergy Clin Immunol 2004, 113, 832-836.

4. Kabashima-Kubo R., Nakamura M., Sakabe J., Sugita K., Hino R., Mori T., et al.: A group of atopic dermatitis without IgE elevation or barrier impairment shows a high Th1 frequency: possible immunological state of the intrinsic type. J Dermatol Sci 2012, 67, 37-43.

5. Yamaguchi H., Hata M., Toshiharu F., Ito T., Hashizume H., Tokura Y.: Psychological aspects of patients with intrinsic atopic dermatitis. Eur J Dermatol 2014, 24, 253-254.

6. Auriemma M., Vianale G., Amerio P., Reale M.: Cytokines and T cells in atopic dermatitis. Eur Cytokine Netw 2013, 24, 37-44.

7. Leiferman K.M.: A role for eosinophils in atopic dermatitis. J Am Acad Dermatol 2001, 45 (1 Suppl.), $21-24$.

8. Novak N., Valenta R., Bohle B., Laffer S., Haberstok J., Kraft S., et al.: FcepsilonRI engagement of Langerhans cell-like dendritic cells and inflammatory dendritic epidermal cell-like dendritic cells induces chemotactic signals and different T-cell phenotypes in vitro. J Allergy Clin Immunol 2004, 113, 949-957.

9. Koga C., Kabashima K., Shiraishi N., Kobayashi M., Tokura Y.: Possible pathogenic role of Th17 cells for atopic dermatitis. J Invest Dermatol 2008, 128, 2625-2630.

10. Kopfnagel V., Harder J., Werfel T.: Expression of antimicrobial peptides in atopic dermatitis and possible immunoregulatory functions. Curr Opin Allergy Clin Immunol 2013, 13, 531-536.

11. Roesner L.M., Heratizadeh A., Begemann G., Kienlin P., Hradetzky S., Niebuhr M., et al.: Der p1 and Der p2-specific T cells display a Th2, Th17, and Th2/Th17 phenotype in atopic dermatitis. J Invest Dermatol 2015, 135, $2324-2327$.

12. Samochocki Z., Alifier M., Bodera P., Jeziorkowska R., Rosiak E., Jurkiewicz B., et al.: T-regulatory cells in severe atopic dermatitis: alterations related to cytokines and other lymphocyte subpopulations. Arch Dermatol Res 2012, 304, 795-801.

13. Novak N., Peng W., Yu C.: Network of myeloid and plasmacytoid dendritic cells in atopic dermatitis. Adv Exp Med Biol 2007, 601, 97-104.

14. Friedmann P.S., Pickard C.: Quantifying human susceptibility to contact sensitization: risk assessments now and in the future. Contact Dermatitis 2010, 63, 237-247.

15. Freudenberg M.A., Esser P.R., Jakob T., Galanos C., Martin S.F.: Innate and adaptive immune responses in contact dermatitis: analogy with infections. G Ital Dermatol Venereol 2009, 144, 173-185.

16. Tsuji R.F., Szczepanik M., Kawikova I., Paliwal V., Campos R.A., Itakura A., et al.: B cell-dependent T cell responses: IgM antibodies are required to elicit contact sensitivity. J Exp Med 2002, 196, 1277-1290.

17. Thyssen J.P., Menne T.: Metal allergy- a review on exposures, penetration, genetics, prevalence, and clinical implications. Chem Res Toxicol 2010, 23, 309-318.

18. Spiewak R., Pietowska J., Curzytek K.: Nickel: a unique allergen - from molecular structure to European legislation. Expert Rev Clin Immunol 2007, 3, 851-859.

19. Thyssen J.P., Linneberg A., Menné T., Johansen J.D.: The epidemiology of contact allergy in the general population - prevalence and main findings. Contact Dermatitis 2007, 57, 287-299.

20. Probst P., Küntzlin D., Fleischer B.: Th2-type infiltrating T cells in nickel-induced contact dermatitis. Cell Immunol 1995, 165, 134-140.

21. Masjedi K., Ahlborg N., Gruvberger B., Bruze M., Karlberg A.T.: Methylisothiazolinones elicit increased production of both T helper (Th)1- and Th2-like cytokines by peripheral blood mononuclear cells from contact allergic individuals. Br J Dermatol 2003, 149, 1172-1182.

22. Goebeler M., Meinardus-Hager G., Roth J., Goerdt S., Sorg C.: Nickel chloride and cobalt chloride, two common contact sensitizers, directly induce expression of intercellular adhesion molecule-1 (ICAM-1), vascular cell adhesion molecule-1 (VCAM-1), and endothelial leukocyte adhesion molecule (ELAM-1) by endothelial cells. J Invest Dermatol 1993, 100, 759-765. 
23. Goebeler M., Trautmann A., Voss A., Bröcker E.V., Toksoy A., Gillitzer R.: Differential and sequential expression of multiple chemokines during elicitation of allergic contact hypersensitivity. Am J Pathol 2001, 158, 431-440.

24. Viemann D., Schmidt M., Tenbrock K., Schmid S., Müller V., Klimmek K., et al.: The contact allergen nickel triggers a unique inflammatory and proangiogenic gene expression pattern via activation of NF-kappaB and hypoxia-inducible factor-1alpha. J Immunol 2007, 178, 3198-3207.

25. Schmidt M., Raghavan B., Müller V., Vogl T., Fejer G., Tchaptchet S., et al.: Crucial role for human Toll-like receptor 4 in the development of contact allergy to nickel. Nat Immunol 2010, 11, 814-819.

26. Lu L., Vollmer J., Moulon C., Weltzien H.U., Marrack P., Kappler J.: Components of the ligand for a Ni+ reactive human T cell clone. J Exp Med 2003, 197, 567-574.

27. Jensen C.S., Menné T., Lisby S., Kristiansen J., Veien N.K.: Experimental systemic contact dermatitis from nickel: a dose response study. Contact Dermatitis 2003, 49, 124-132.

28. Sharma A.D.: Relationship between nickel allergy and diet. Indian J Dermatol Venereol Leprol 2007, 73, $307-312$.

29. Veien N.K., Andersen M.R.: Nickel in Danish food. Acta Derm Venereol 1986, 66, 502-509.

30. Ysart G., Miller P., Croasdale M., Crews H., Robb P., Baxter M., et al.: 1997 UK Total Diet Study--dietary exposures to aluminium, arsenic, cadmium, chromium, copper, lead, mercury, nickel, selenium, tin and zinc. Food Addit Contam 2000, 17, 775-786.

31. Calnan C.D.: Nickel dermatitis. Br J Dermatol 1956, 68, 229-236.

32. Shanon J.: Pseudo-atopic dermatitis. Contact dermatitis due to chrome sensitivity simulating atopic dermatitis. Dermatologica $1965,131,176-190$

33. De C.P., Decock P.A., Shanon J.: Pseudo-atopic dermatitis. An example of pseudo-nomenclature. Dermatologica 1966, 133, 236-237.

34. Spiewak R., Moed H., von Blomberg B.M., Bruynzeel D.P., Scheper R.J., Gibbs S., et al.: Allergic contact dermatitis to nickel: modified in vitro test protocols for better detection of allergen-specific response. Contact Dermatitis 2007, 56, 63-69.

35. Hamid Q., Naseer T., Minshall E.M., Song Y.L., Boguniewicz M., Leung D.Y.: In vivo expression of IL-12 and IL-13 in atopic dermatitis. J Allergy Clin Immunol 1996, 98, 225-231.

36. Suárez-Fariñas M., Dhingra N., Gittler J., Shemer A., Cardinale I., de Guzman Strong C., et al.: Intrinsic atopic dermatitis shows similar TH2 and higher TH17 immune activation compared with extrinsic atopic dermatitis. J Allergy Clin Immunol 2013, 132, 361-370.

37. Neis M.M., Peters B., Dreuw A., Wenzel J., Bieber T., Mauch C., et al.: Enhanced expression levels of IL-31 correlate with IL-4 and IL-13 in atopic and allergic contact dermatitis. J Allergy Clin Immunol 2006, 118, 930-937.

38. Dotterud L.K., Smith-Sivertsen T.: Allergic contact sensitization in the general adult population: a population-based study from Northern Norway. Contact Dermatitis 2007, 56, 10-15.

39. Thyssen J.P., Linneberg A., Engkilde K., Menné T., Johansen J.D.: Contact sensitization to common haptens is associated with atopic dermatitis: new insight. Br J Dermatol 2012, 166, 1255-1261.

40. Thyssen J.P., Carlsen B.C., Menné T., Linneberg A., Nielsen N.H., Meldgaard M., et al.: Filaggrin null mutations increase the risk and persistence of hand eczema in subjects with atopic dermatitis: results from a general population study. Br J Dermatol 2010, 163, 115-120.

41. Klimańska M., Jenerowicz D., Czarnecka-Operacz M.: The importance of exposure to contact allergens in patients with allergic contact dermatitis. Post Dermatol Alergol 2011, 28, 203-211.

42. Ograczyk A., Miniszewska J., Zalewska-Janowska A.: Psychological aspects of atopic dermatitis and contact dermatitis: stress coping strategies and stigmatization. Post Dermatol Alergol 2012, 29, 14-18.

43. Isaksson M., Olhardt S., Rådehed J., Svensson Å.: Children with atopic dermatitis should always be patch-tested if they have hand or foot dermatitis. Acta Derm Venereol 2015, 95, 583-586.

44. Stoškutè L., Tamošiūnas V.A.: Allergic contact dermatitis and patch testing in children. Acta Medica Lituanica 2005, 12, 71-74

45. Yamaguchi H., Kabashima-Kubo R., Bito T., Sakabe J., Shimauchi T., Ito T., et al.: High frequencies of positive nickel/cobalt patch tests and high sweat nickel concentration in patients with intrinsic atopic dermatitis. J Dermatol Sci 2013, 72, 240-245.

46. Palmer C.N., Irvine A.D., Terron-Kwiatkowski A., Zhao Y., Liao H., Lee S.P., et al.: Common loss-of-function variants of the epidermal barrier protein filaggrin are a major predisposing factor for atopic dermatitis. Nat Genet 2006, 38, 441-446.

47. Cork M.J., Danby S.G., Vasilopoulos Y., Hadgraft J., Lane M.E., Moustafa M., et al.: Epidermal barrier dysfunction in atopic dermatitis. J Invest Dermatol 2009, 129, 1892-1908.

48. O'Regan G.M., Sandilands A., McLean W.H., Irvine A.D.: Filaggrin in atopic dermatitis. J Allergy Clin Immunol 2008, 122, 689-693.

49. Thyssen J.P., Carlsen B.C., Menne T.: Nickel sensitization, hand eczema, and loss-of-function mutations in the filaggrin gene. Dermatitis 2008, 19, 303-307.

50. Tokura Y.: Extrinsic and intrinsic types of atopic dermatitis. J Dermatol Sci 2010, 58, 1-7.

51. Onder M., Adisen E.: Patch test results in a Turkish paediatric population. Contact Dermatitis 2008, 58, 63-65.

Received: 20.12 .2016

Accepted: 17.03 .2017

Otrzymano: 20.12 .2016 r.

Zaakceptowano: 17.03 .2017 r.

How to cite this article

Rożalski M., Blicharz L., Samochocki Z.: Contact hypersensitivity to nickel in patients with atopic dermatitis. Dermatol Rev/ Przegl Dermatol 2017, 104, 133-141. DOI: https:/ / doi.org/10.5114/dr.2017.67388 